\title{
Notes on Japanese Names and Terms
}

Japanese names, when cited in full, are written family name first. I have followed the Japanese convention by referring to writers by their pen names (e.g., Shōyō instead of Tsubouchi); for those writers who used their own names or those whose full names were pen names, I have referred to them by their family name (e.g., Fukuzawa for Fukuzawa Yukichi and Futabatei for Futabatei Shimei, a pen name for Hasegawa Tatsunosuke). For pre-Meiji writers, I have again followed the Japanese scholarly convention of referring to their given names (e.g., Akinari for Ueda Akinari). Names of writers of works in English, however, follow the order given in the publication. Japanese common nouns and proper nouns that appear in English-language dictionaries are rendered in roman type without macrons. All other Japanese terms are italicized with macrons used to indicate long vowels. All translations from the Japanese, unless otherwise noted, are mine. 

Concealment of Politics, Politics of Concealment 
